\title{
Diacronie
}

Studi di Storia Contemporanea

$\mathrm{N}^{\circ} 36,4 \mid 2018$

Viaggi e turismo nell'Europa del Novecento

\section{"All Aboard for Europe!": American Youth Travel to Europe Between the World Wars}

\section{Katherine Cartwright}

\section{Q OpenEdition \\ 1 Journals}

\section{Electronic version}

URL: https://journals.openedition.org/diacronie/10603

DOI: 10.4000/diacronie.10603

ISSN: 2038-0925

\section{Publisher}

Association culturelle Diacronie

\section{Electronic reference}

Katherine Cartwright, "'All Aboard for Europe!": American Youth Travel to Europe Between the World Wars", Diacronie [Online], N 36, 4 | 2018, document 11, Online since 29 December 2018, connection on 17 February 2022. URL: http://journals.openedition.org/diacronie/10603 ; DOI: https://doi.org/ 10.4000/diacronie.10603 


\title{
Diacronie
}

Studi di Storia Contemporanea

$36,4 / 2018$

Viaggi e turismo nell'Europa del Novecento

\section{“All Aboard for Europe!": American Youth Travel to Europe Between the World Wars}

\author{
Katherine CARTWRIGHT
}

Per citare questo articolo:

CARTWRIGHT, Katherine, «"All Aboard for Europe!”: American Youth Travel to Europe Between the World Wars», Diacronie. Studi di Storia Contemporanea : Viaggi e turismo nell'Europa del Novecento, 36, 4/2018, 29/12/2018,

URL: < http://www.studistorici.com/2018/12/29/cartwright_numero_36/ >

Diacronie Studi di Storia Contemporanea $\rightarrow$ http://www.diacronie.it

Rivista storica online. Uscita trimestrale.

redazione.diacronie@hotmail.it

Comitato di direzione: Naor Ben-Yehoyada - João Fábio Bertonha - Christopher Denis-Delacour - Maximiliano Fuentes Codera Anders Granås Kjøstvedt - John Paul Newman - Deborah Paci - Niccolò Pianciola - Spyridon Ploumidis - Wilko Graf Von Hardenberg

Comitato di redazione: Jacopo Bassi - Luca Bufarale - Gianluca Canè - Luca G. Manenti - Fausto Pietrancosta - Alessandro Salvador - Matteo Tomasoni - Luca Zuccolo

Diritti: gli articoli di Diacronie. Studi di Storia Contemporanea sono pubblicati sotto licenza Creative Commons 3.0. Possono essere riprodotti e modificati a patto di indicare eventuali modifiche dei contenuti, di riconoscere la paternità dell'opera e di condividerla allo stesso modo. La citazione di estratti è comunque sempre autorizzata, nei limiti previsti dalla legge. 


\title{
11/ "All Aboard for Europe!": American Youth Travel to Europe Between the World Wars
}

\author{
Katherine CARTWRIGHT
}

\begin{abstract}
Using the travel writing of six Americans in their teens who went to Europe between WWI and WWII, this article argues that broader trends of mass tourism, such as travel's extension beyond European elite and inclusion of women, intersected with Americans' preoccupation with youth and youth culture in the interwar years. First, an examination of publications aimed at middle-class Americans demonstrates that contemporaries saw travel as a way to mitigate anxieties about youth, nationalism, and internationalism. Then, a close reading of the youths' writing reveals that as young American women growing up in a period in which anxieties about youth and young women's sexuality were high, their gender and age were crucial to how they made sense of their social and political experiences abroad.
\end{abstract}

\section{Introduction}

As fourteen-year-old Victoria Brown set sail for Europe in 1935 she sketched a picture in her diary. A girl, presumably Victoria herself, waves goodbye to the New York City skyline as she gazes at a circular buoy with the name of the ship that would carry her to Europe: «S.S. Champlain». Across the top of the page she wrote, "Goodbye USA». Fifteen-year-old Clara Schiefer, sixteen-year-olds Anna Taylor and Rosalie Durrette, and nineteen-year-olds Yvonne Blue and Eleanor Winograd offered similar descriptions in their travel writing in the late 1920s and $1930 \mathrm{~s}^{2}$. These American youths recorded detailed accounts of their trips until they returned

\footnotetext{
${ }^{1}$ I would like to thank Phillip Emanuel, David (Mac) Marquis and Nadine Zimmerli for reading drafts of this article. Victoria Brown Travel Diary of Europe, 1935, SC 00002, Special Collections, Swem Library, College of William and Mary, Aug. 16, Part I, p. 65. Henceforth referred to as Victoria Brown Travel Diary.

${ }^{2}$ Clara Louise Schiefer Diary, 1933, SC 00724, Special Collections, Swem Library, College of William and Mary; Anna Taylor Diary, 1929, Mss. Acc. 2011.569, Special Collections Swem Library, College of William and Mary; Rosalie D.J. McLeod Diary, 1937, SC 01264, Special Collections Swem Library, College of William and Mary; Yvonne Blue Skinner Papers. Schlesinger Library, Radcliffe Institute, Harvard University, M-26, Reel 2, 8v; and Recollections of 1936 Trip, between 1990-2007. Winograd Judd Family Papers, B266.04.0008.0001.
} 
home weeks and sometimes months later, yet their experiences and those of others like them have yet to be studied. While scholars such as Brooke Blower and Whitney Walton have considered the experience of Americans in Europe between the world wars, what has not been considered is youth travel - both actual travel and representations of it back in the United States - outside of formal collegiate study abroad and exchange programs ${ }^{3}$. Studying these youths and the types of trips they undertook draws attention to trends of mass tourism in the twentieth century, such as travel's extension to those beyond European elites and the inclusion of women, but specifically shows how these trends intersected with adult Americans' preoccupation with youth and youth culture in the interwar years.

A brief introduction to the young Americans allows for a better understanding of them, their trips, and the writing they left behind. They were between fourteen and nineteen years old and census records indicate that they hailed from predominantly white, middle- and upper-middleclass communities. Sixteen-year-old Anna traveled with her mother and a tour group in 1929, visiting England, Germany, Switzerland, Italy, Belgium, the Netherlands, and France. Nineteenyear-old Yvonne embarked on a similar tour of Europe with a travel group a year later. Fifteenyear-old Clara visited Europe in 1933 without her parents, instead traveling through a Boy Scout and Girl Scout exchange. Neither fourteen-year-old Victoria, traveling in 1935, nor nineteen-yearold Eleanor, traveling in 1936, traveled with tour groups. Instead, Victoria went abroad to visit France and Italy with her parents and younger sister. And, though Eleanor did begin her trip with a group of students, the writing examined here was kept after parting ways with the group to visit family. Finally, sixteen-year-old Rosalie undertook the most extensive travels with her father and through a travel agency in 1937, visiting cities from Paris to Moscow ${ }^{4}$. The variety of these trips -

Beck Archives of Rocky Mountain Jewish History, Special Collections, University of Denver. Within the Winograd Judd Family Papers, is Eleanor's transcription of her travel diary. She transcribed it for publication in the Spring 1984 issue of Rocky Mountain Jewish Historical Notes. This article uses the original transcription, not the published version. The travel writing is henceforth referred to as: Clara Schiefer Diary, Anna Taylor Diary, Rosalie McLeod Diary, Yvonne Blue Travel Diary, Eleanor Winograd Travel Writing Transcript.

The youths' writing informs the use of "American" in this article. Their writing suggests that they defined being "American" as a citizen of the United States.

${ }^{3}$ BLOWER, Brooke L., Becoming Americans in Paris: Transatlantic Politics and Culture Between the World Wars, Oxford, Oxford UP, 2011; WALTON, Whitney, «Internationalism and the Junior Year Abroad: American Students in France in the 1920s and 1930s», in Diplomatic History, 29, 2/2005, pp. 255-278.

${ }^{4}$ Understanding the diaries of Clara, Victoria, Anna, and Yvonne as “public' private diaries», meaning that the young women wrote their diaries with a conscious or unconscious audience in mind, allows for them to be studied together with the writings of Rosalie, who dedicated the transcription of her diary to her father, and Eleanor, who transcribed her diary to be published in the Rocky Mountain Jewish Historical Notes later in life. My understanding of diaries as sources comes from Lynn Bloom in BEATTIE, Heather, «Where Narratives Meet: Archival Description, Provenance, and Women's Diaries», in Libraries \& the Cultural Record 44, 1/2009, pp. 82-100, pp. 93; SCHRIBER, Suzanne Mary, Writing Home: American Women Abroad, 1830-1920, Charlottesville, University of Virginia Press, 1997; HARRISON, Kimberly, «Rhetorical Rehearsals: The Construction of Ethos in Confederate Civil War Diaries», in Rhetoric Review, 22, 3/2003, pp. 243-263, p. 244; SCHRUM, Kelly, Some Wore Bobby Sox: The Emergence of Teenage Girls' Culture, New York, Palgrave Macmillan, 
youth exchanges, tours with travel groups, and independent family travel - in fact represents the various modes of travel possible for American young people in the interwar years.

The travel writing of these young Americans offers the opportunity to probe questions about young people, tourism, and internationalism between the world wars and provides the opportunity to include young women's voices in answering these questions ${ }^{5}$. In order to understand the context in which these young Americans went abroad, I first examine the magazines and newspapers mentioned in the youths' writing and complement them with publications aimed at middle-class Americans in order to show that contemporaries saw travel as a way to mitigate anxieties about American youth, nationalism, and internationalism between the world wars. A close reading of the youths' travel writing then reveals that they did not just fulfill the desires of their adult contemporaries who deemed travel as something that would prepare the youths to be productive citizens of both the country and the world. Instead they imbued their trips with their own meaning: age and gender were integral to how these youths understood themselves, their social interactions outside of the U.S., and the cultures and forms of government they encountered as they traveled. Thus although adults might have encouraged travel as a way to mitigate anxieties about youth in the interwar years, in reality the concerns over youthful sexuality and prescribed gender roles that fueled these anxieties were in fact integral to how the young Americans examined here made sense of their trips.

Considering how middle-class American youth and their parents understood travel and tourism is one way to internationalize scholarship on young people's experience in the twentieth century. Even though scholars draw attention to the 1920s and 1930s as important decades for the development of youth culture in the American context due to increased consumerism and school attendance, few are asking questions that move beyond the country's borders ${ }^{6}$. Even those who

2004, p. 180, footnote 15; BRUMBERG, Joan, The Body Project: An Intimate History of American Girls, New York, Vintage Books, 1997, p. xxvii. "Fifteenth Census of the United States (1930)," Flossmoor, Cook, Illinois, Scanned Image, Ancestry.com Roll: 2340149; Page 12B; Enumeration District: 2332, accessed March 3, 2017; Houston, Harris, Texas, Scanned Image, Ancestry.com Roll: 2342083; Page 10A; Enumeration District: 0108, accessed March 3, 2017; and Brighton, Monroe, New York, Scanned Image, Ancestry.com Roll: 2341181; Page 22B; Enumeration District: 0201, accessed March 3, 2017. "Sixteenth Census of the United States (1940)," Hillsborough, San Mateo, California, Ancestry.com Roll: T627_330; Page 30A; Enumeration District: 41-30, accessed March 3, 2017. The young women were from: Texas (Anna), Illinois (Yvonne), New York (Clara), California (Victoria), Colorado (Eleanor), and Virginia (Rosalie).

${ }^{5}$ I am using the terms "youth" and, more broadly, "young people" because I understand these categories as fluid identities with which people can choose to self-identify. Their use in this article is informed by the youths' writing which indicates that they identified themselves and their peers as part of a distinct age cohort. I use "youth in their teens" - rather than "teenagers" - because "teenagers" was not widely used until the 1940s. When referring to the individuals, I use "youth" and "young women" to help readers avoid imposing contemporary understandings about girlhood and womanhood to the historical actors studied in this paper. Age, like gender and race, is an arbitrary category that is imbued with social meaning and understanding within a specific historical moment. See MINTZ, Stephen, «Reflections on Age as a Category of Historical Analysis», in Journal of the History of Childhood and Youth, 1, 1/2008, pp. 91-94, pp. 92-93.

${ }^{6}$ For works that draw attention to the 1920 s and 1930s as significant to the development of "youth culture" 
have begun to ask these questions, such as Jennifer Helgren in her study of American girls' "youth internationalism» and Richard Ivan Jobs in his work on young backpackers in Europe, overwhelmingly concentrate on the post-1945 period ${ }^{7}$. That said, evidence of internationalism or an attention to different cultures and the international connections among people - in the interwar period is not all that surprising given recent scholarship that seeks to expand studies of foreign relations and "internationalize" the history of the U.S. by exploring topics such as consumerism, education, and tourism. Kristin Hoganson, for example, finds an intense interest in products from abroad by looking at middle-class domestic spaces in her study of American consumerism ${ }^{8}$. Moving beyond state actors and formal government policy has been particularly fruitful for challenging the characterization of the interwar years as a period of U.S. history that was isolationist. Despite rejection of the League of Nations, immigration restrictions, and a move away from the internationalist rhetoric of the Wilsonian years, Diana Selig finds a robust educational push to teach young people global citizenship and appreciation for the country's cultural diversity 9 . Similarly, in their studies of adult expatriates, businessmen, and Junior Year Abroad participants in France, Brooke Blower and Whitney Walton identify Americans working out their national identities in international contexts ${ }^{10}$.

Through such topics, scholars are contributing to larger questions about internationalism and including women - as intellectuals, tourists, and educators - and young people - as students - in their studies. Scholars studying "internationalism" often build on Akira Iriye's specification of «cultural internationalism» that refers to projects that sought to spread awareness of different cultures and encourage interconnectedness among people beyond national borders ${ }^{11}$. In the

in the United States see BAILEY, Beth, From Front Porch to Back Seat: Courtship in Twentieth-Century America, Baltimore, Johns Hopkins UP, 1988; FASS, Paula, The Damned and the Beautiful: American Youth in the 1920s, New York, Oxford UP, 1977; JACOBSON, Lisa, Raising Consumers: Children and the American Mass Market in the Early Twentieth Century, New York, Columbia UP, 2004; SCHRUM, Kelly, Some Wore Bobby Sox: The Emergence of Teenage Girls' Culture, New York, Palgrave Macmillan, 2004.

${ }^{7}$ HELGREN, Jennifer, American Girls and Global Responsibility: A New Relation to the World During the Early Cold War, Rutgers, Rutgers UP, 2017; JOBS, Richard Ivan, Backpack Ambassadors: How Youth Travel Integrated Europe, Chicago, The University of Chicago Press, 2017.

${ }^{8}$ HOGANSON, Kristin L., Consumers' Imperium: The Global Production of American Domesticity, 1865-1920, Chapel Hill, University of North Carolina Press, 2007.

${ }^{9}$ SELIG, Diana, Americans All: The Cultural Gifts Movement, Cambridge, Harvard UP, 2008. See also: SELIG, World Friendship: Children, Parents, and Peace Education in America in Between the Wars, in MARTEN, James Alan (edited by), Children and War: A Historical Anthology, New York, New York UP, 2002, pp. 135-146. Other schoolars studying education include: BU, Liping, Making the World Like Us: Education, Cultural Expansion, and the American Century, Westport, CT, Praeger Publishers, 2003; KRAMER, Paul A., «Is the World Our Campus? International Students and U.S. Global Power in the Long Twentieth Century», in Diplomatic History, 33 5/2009, pp. 775-806.

${ }^{10}$ BLOWER, Brooke, op. cit; WALTON, Whitney, «Internationalism and the Junior Year Abroad», cit. See also WALTON, Whitney, Internationalism, National Identities, and Study Abroad: France and the United States, 1890-1970, Stanford, Stanford UP, 2010; GREEN, Nancy L., The Other Americans in Paris: Businessmen, Countesses, Wayward Youth, 1880-1941, Chicago, University of Chicago Press, 2014.

${ }^{11}$ IRIYE, Akira, Cultural Internationalism and World Order, Baltimore, Johns Hopkins UP, 1997, p. 2. Iriye argues that the interwar period is when «culture internationalism came of age», p. [51]. 
context of the American interwar years, internationalism is often associated with Americanization: the process by which private citizens and groups (knowingly or unknowingly) promoted American practices through business or mass culture ${ }^{12}$. These two ways of thinking may appear to pit internationalism against nationalism, however, scholarship on travel, tourism, and consumption shows that nationalism and internationalism should not be seen as mutually exclusive. An individual can simultaneously maintain their national loyalty and experience an appreciation for national cultures that are different from their own. Walton and Blower especially stress this in their studies of interwar tourists. As Blower argues, "Americanness was not simply American-made». It was something "worked out in international contexts» ${ }^{13}$. The young Americans studied here joined their fellow interwar tourists who worked out their "Americanness" in international spaces, but as young American women growing up in a period in which anxieties about youth and young women's sexuality were high, their gender and age were crucial to how they understood and processed their social and political experiences abroad.

\section{Youth Travel in the Century of the Child and Interwar Years of Crisis}

When these young Americans left the shores of the U.S. they joined a long tradition of Americans visiting Europe. Though originally reserved for a small group of elite men, as the nineteenth century progressed and travel became more comfortable and less expensive, tourism expanded to those beyond the upper classes and increasingly included women. Partially due to the introduction of the Tourist Third Cabin in 1925, the number of Americans traveling abroad reached a new high in the mid-1920s, with those going to Europe growing more than 100 percent from 1924 to 1930 . By 1928, about 800,000 tourists traveled in the "Tourist Third" alone ${ }^{14}$. While previously people saw the Grand Tour and the exposure it provided to 'Old World Civilization' history, art, and architecture as a means of self-improvement and cultural refinement, by the 1920s they deemed «recreational tourism - having a good time, having fun» as accomplishing the same goals ${ }^{15}$. The lure of going abroad shifted from exposure to culture and art to the ability to

\footnotetext{
${ }^{12}$ See especially WALTON, Whitney, «Internationalism and the Junior Year Abroad», cit., p. 257.

${ }^{13}$ BLOWER, Brooke, op. cit., pp. 11, 38.

${ }^{14}$ Ibidem, pp. 21-22. Steamship companies replaced "Steerage" with "Tourist Third Cabin" in order to attract middle-class passengers after the Johnson Reed Act of 1924 severely cut immigration across the Atlantic. See: COONS, Lorraine, VARIAS, Alexander, Tourist Third Cabin: Steamship Travel in the Interwar Years, New York, Palgrave Macmillan, 2003.

${ }^{15}$ LEVENSTEIN, Harvey, Seductive Journey: American Tourists in France From Jefferson to the Jazz Age, Chicago, University of Chicago Press, 1998, pp. 255-256. Most scholars of travel and tourism argue that as the purpose of travel shifted away from cultural appreciation, refinement, and education toward activities associated with leisure and pleasure seeking, travelers - in other words, active participants who explored new places - became tourists, passive participants who experienced the places they visited through the lens of mediators. I use "youth travel" in this article because this is how Americans in the 1920s and 1930s
} 
shop, drink, and participate in the more sexually liberal culture Europe was thought to offer. Nonetheless, some of the trips examined here were given as gifts and undertaken before the youths entered college, which indicates that traveling had residual significance into the twentieth century as a sign of coming of age or cultural refinement.

Not only were more Americans traveling to Europe than ever before, travel to Europe filled the publications middle-class Americans read. Kristin Hoganson identifies a «culture of international travel» - or, «a culture permeated with reports and images of foreign travel, a culture rife with ersatz travel experiences» - in her study of middle-class domestic spaces from 1865 to $1920^{16}$. Likewise, Christopher Endy asserts a similar phenomenon in his study of popular commentary on travel to Europe in U.S. publications leading up to World War One ${ }^{17}$. Accounts of Americans traveling and living in Europe were thus common in U.S. popular culture from the late nineteenth century through the end of World War One. Publications from the 1920s and 1930s indicate the continued representation of Americans in Europe in U.S. popular culture. More specifically, articles and advertisements indicate that youth travel to Europe became especially prominent: authors increasingly identified American young people as the ideal Americans to go abroad and wrote for an audience of American youths and their parents. While articles about youth travel appeared in the late teens, they appeared more frequently as the interwar years progressed. Though coverage of youth travel to Europe would dwindle during World War Two, it would pick up again after the war ${ }^{18}$.

Publications aimed at middle-class Americans like the youths examined here and their parents positioned travel to Europe as a way to mitigate anxieties surrounding young people and the United States' place on the international stage. Scholars attribute the emergence of youth culture from about the turn of the century through the 1930s to shifting family structures, the increasing availability of heterosocial leisure spaces, and the mass consumption of consumer goods and entertainment. Adults progressively saw the growing autonomy and mobility of youth as a threat to their authority and pinned society's problems on the group's growing identification ${ }^{19}$. The perceived threat of youth was particularly acute in the late 1920s and early 1930s because of the Depression and the growing popularity of communism and fascism in Europe, as a large number

overwhelmingly referred to the type of trips examined here.

${ }^{16}$ HOGANSON, Kristin L., op. cit., p. 165.

${ }^{17}$ ENDY, Christopher, «Travel and World Power: Americans in Europe, 1890-1917», in Diplomatic History, 22, 4/1998, pp. 565-594, p. 569.

${ }^{18}$ See: HELGREN, Jennifer, op. cit;; JOBS, Richard Ivan, op. cit.

${ }^{19}$ The 1904 publication of G. Stanley Hall's two-volume study, Adolescence, marked the explicit recognition of a distinct life stage between the ages of twelve and twenty-one for girls and fourteen to twenty-five for boys. While this life stage was recognized in the early twentieth century, it was not until the 1920s that a visible national youth culture was established. See SCHRUM, Kelly, op. cit., pp. [11]-12; D'EMILIO, John, FREEDMAN, Estelle B., Intimate Matters: A History of Sexuality in America, Chicago, University of Chicago Press, 2012, especially Chapter Eleven. 
of Americans came to associate the "youth problem» with the "crisis of civilization» ${ }^{20}$. In short, as the fate of both the country and civilization became seen as inextricably linked to youths, young people and their habits created much anxiety among older Americans. As a result, liberal educators, adults, and reformers sought ways to relieve this anxiety by refining the future generations into their version of good, American citizens.

Travel, educators and reformers believed, was one way to teach the young how to be productive citizens of both the U.S. and the world. Articles about the Junior Year Abroad inaugurated at the University of Delaware in 1923 - particularly highlighted the importance of international experience to the United States' place in the world:

The World War dragged us out of our isolation and we are today acting a part on the world stage. If we do not want to be the unconsciously humorous character in the drama, we must know foreign languages, literatures, cultures, and ideals ${ }^{21}$.

While Whitney Walton demonstrates that adults - from diplomats to educators - debated exactly how experience abroad would strengthen Junior Year Abroad students' attachment to the U.S. and facilitate an appreciation for other cultures, similar debates occurred among educators of younger students ${ }^{22}$. Articles aimed at primary and secondary educators stressed the importance of teaching students the benefits of international cooperation. In 1930 Caroline Barbour began her article in Childhood Education, «The twentieth century's gift to the history of evolution will be World Federation» made possible because the twentieth century was also the "Century of the Child»" ${ }^{23}$. Since more children than ever before were going to school, classrooms that taught global mindedness could surely make a difference. Activities, such as reading about foreign lands and travel, would teach students to value the U.S., but also foster a curiosity and

\footnotetext{
${ }^{20}$ BERGLER, Thomas E., «Youth, Christianity, and the Crisis of Civilization, 1930-1945», in Religion \& American Culture, 24, 2/2014, pp. 259-260.

${ }^{21}$ COOPER, William A., «The Junior Year in Germany», in Monatshefte Für Deutschen Unterricht, 23, 7/1931, p. 220. Another example includes MÉRAS, Edmond A., "World-Mindedness», in The Journal of Higher Education, 3, 5/1932, p. 246. Similar messages had appeared in travel periodicals aimed at middle-class women since the late nineteenth century. See Chapter Four: "Girdling the Globe: The Fictive Travel Movement and the Rise of the Tourist Mentality" in HOGANSON, op. cit., pp. 153-208.

${ }^{22}$ WALTON, Whitney, «National interests and cultural exchange in French and American educational travel, 1914-1970», in Journal of Transatlantic Studies, 13, 4/2015, pp. 255-278, p. 345.

${ }^{23}$ BARBOUR, Caroline W., "Getting Acquainted with Our Neighbors», in Childhood Education, 7, 4/1930, p. 196. Other examples include: MEAD, Lucia Ames, «Value of Foreign Travel», in Journal of Education 108, 18/1928, pp. 464-465; MAHONEY, Bertha E., "Far Horizons in Spring Books for Boys and Girls», in Elementary English Review, 6, 6/1929, pp. 143-146; JACKSON, Annie, «Book Friends of Many Nations», in Elementary English Review, 8, 8/1931, pp. 181-184; BOARDMAN, Bertha T., «Builders of Goodwill», in Christian Education, 18, 2/1934, pp. 84-98; SHAW, Margaret, «A Bridge of International Friendship», in The Elementary English Review, 13, 5/1936, pp. 170-194; EDMAN, Marion, “"Disarm the Hearts”: Developing a Feeling of World Friendship», in The Elementary English Review, 16, 5/1939, pp. 176-190. For a school teacher soliciting the government to join the push to connect American students with students abroad, see: CROWELL, E.C., «Letters to the Editor: Travel for School Children», in New York Times, June 4, 1935, p. 22.
} 
appreciation for those that were different from them. Read together, the articles show the importance contemporary educators placed on youth travel as a means to instill in the young of all ages an international consciousness.

Everyday readers encountered similar messages about travel in newspapers and magazines that targeted the middle class. A good example of this is Sydney Greenbie's article "World Consciousness" in the women's periodical «Redbook Magazine». Like the writers in education journals, Greenbie positioned travel as a way to foster an international outlook, while also encouraging a natural attachment to the youths' own country: «[travel] is an excellent preventive of provincial narrowness and bigotry; and an estimable aid in fostering that world-consciousness which will be one of the distinguishing marks of the cultivated person». The article also addressed some of the anxieties surrounding travel:

Sometimes the criticism is heard that foreign study and travel in early life may alienate our youth from American institutions. Nothing could be more fallacious. Experience shows that an early acquaintance with the customs and manners of other people, instead of scattering a man's attachments, intensifies his love for his home land ${ }^{24}$.

These excerpts are significant in that they capture the national debate surrounding youth travel. Some Americans saw travel - perhaps like the League of Nations that the country refused to join - as a threat to the country's well-being, an activity that would erode youths' national loyalty. Others deemed travel to be exactly what the country needed: a way to gain prominence on the international stage. Greenbie captured the middle ground that most educators and middleclass writers took. Travel, its proponents argued, would both strengthen a child's nationalism and internationalism and, most importantly, strengthen their and their country's place in the world.

Such excerpts also draw attention to the gendered language used in the interwar discourse of youth travel. Like Greenbie, who wrote that travel would intensify "his love for his home land" (emphasis added), authors often universally referred to young people using "he" or "him." While masculine pronouns were often the default during this period, the fact that the discourse of youth travel intersected with topics of citizenship and nationalism draws attention to how contemporary writers and educators overwhelmingly envisioned the young boy turned man as the ideal citizen. This was despite the fact that women had recently been recognized as full citizens with voting rights with the ratification of the Nineteenth Amendment in 1920.

\footnotetext{
${ }^{24}$ GREENBIE, Sydney, «World Consciousness», in Red Book Magazine, 51, 6/1928, p. 6. Other examples include O’DONNELL, Frances Frisbie, «Education Via Travel», in Parents' Magazine, 9, 6/1934, pp. 24-25, 71; CASSIDY, Mills, «Educational Values of Travel Stressed in European Countries», in New York Times, August 8, 1937, p. 5; RICHMOND, Alice Clarissa, «Early Travel Training Good for Children», in Washington Post, February 11, 1937, p. 11; CURTIS, Helen Perry, «Travel is a Liberal Education», in Parents' Magazine, 14, 4/1939, p. 17.
} 
Contemporaries rarely explicitly recognized the importance of the increasing availability of travel for specifically girls and women or connected their travels to citizenship training, even though young women were prominent in Junior Year Abroad programs and the travel groups of the youth examined here were made up of many girls and women. Though neglected by their contemporaries, their experiences are key for understanding the extension of travel in the twentieth century to include middle-class American girls and women. The travel writing examined here thus offers one way to examine this shift by including the voices of young women and asking how both their age and gender shaped their experiences.

Though often using a gendered language that prioritized boys and young men, throughout the publications everyday Americans read, articles and advertisements promoted and encouraged youth travel to adults and young people alike. For example, in «Parents' Magazine», articles like "Education Via Travel" and "Travel is a Liberal Education" encouraged parents to take their children abroad, especially to Europe ${ }^{25}$. These articles stressed the educational values of travel, but specifically delegated this "global mindedness" as the parents' responsibility. If a parent did not have the time or money to go abroad with their children, articles suggested that parents send their children abroad through exchanges or with student travel groups. No matter the type of travel, it was one way parents could complete their responsibility of fostering a global mindedness among their children.

Other articles offered tips for parents traveling with their children. These included encouraging children to keep journals, traveling to places that would augment the child's studies, and preparing the children through activities at home before their trips ${ }^{26}$. In general, the articles advised that intensive travel through Europe was not recommended for very young children, but «with older children» - those at least in high school - «the rewards of a well-planned trip are many» ${ }^{27}$. Though it is impossible to know if the parents of the young Americans examined here read these exact articles, the youths' writing indicates that their parents did do the things mentioned in them. Many of the youths' trips mimicked their language preparation in school and all of them indeed kept a travel journal. Moreover, the pervasiveness of such topics across different types of publications makes it hard to imagine that the youths and their parents did not come across similar articles.

\footnotetext{
${ }^{25}$ O'DONNELL, Frances, op. cit.; and CURTIS, Helen, op. cit. See also «Travel: The Happiest Educator», in Red Book Magazine, 43, 4/1924, p. 140; VAN HOOK, Edith, «All Aboard for Europe!», in Parents' Magazine, 11, 7/1927, pp. 20-21; SHULTZ, Denny Gladys, «Never Too Young To Travel», in Better Homes and Gardens, 15, 11/1937, pp. 62-65; LITTLEDALE, Clara Savage, "Travel Together», in Parents' Magazine, 14, 4/1939, p. 17.

${ }^{26}$ In addition to the articles above, see «Travel Togs for Tots», in Washington Post, July 22, 1917, p. 5; HUNTINGTON, Gladys Bevans, «You and Your Children: How Do You Travel With the Children?», in Chicago Daily Tribune, August 26, 1927, p. 24; CANFIELD, Katharine Emmet, «Travel: Taking Children to Europe», in Vogue, 75, 12/1930, pp. 54-55, 120, 128.

${ }^{27}$ VAN HOOK, Edith, op. cit., pp. 20. See also O'DONNELL, Frances, op. cit., p. 25.
} 
Advertisements were also common throughout these publications and specifically aimed to attract youths and their parents by emphasizing lower rates for those under nineteen, as well as specific provisions aimed at them. A "Student European Tour" advertisement read, $" 6^{\text {th }}$ Annual Tour...Sailing S.S. Bremen July $3^{\text {rd }} .48$ days. Price $\$ 395$ to those under 19 yrs. $\$ 465$ to adults» ${ }^{28}$. Ocean liners and travel agencies also produced pamphlets and digests to advertise their services. These pamphlets highlighted how stress-free travel would be through the agencies, and the ship companies even had specific menus and parties for children ${ }^{29}$. Through these publications, the travel industry projected an image of travel as a carefree and affordable pursuit for Americans and suggested that while crossing the Atlantic passengers would meet "congenial people» ${ }^{30}$. All in all, these advertisements painted the trans-Atlantic journey and touring Europe as easy and exciting endeavors for Americans, and particularly for American youth.

Even those who never left the U.S. read about their contemporaries - both old and young that did. Articles encouraged readers to find out about the travels of radio and movie stars with catchy titles like "Pic People Forget 'See America First,' as They Trek to Europe" and also tracked the everyday American, as clippings that Clara pasted in her diary indicate ${ }^{31}$. Leading up to her trip, she pasted newspaper clippings that announced her travel plans from Rochester, New York's The Daily Record in her diary. And, upon her return, she pasted more clippings that showed that while she traveled, her community at home followed her journey (see Image 1$)^{32}$. Other articles chronicled the experience of children traveling alone, students studying abroad, and young travelers taking advantage of the growing number of youth hostels ${ }^{33}$. Published travel accounts by

\footnotetext{
28 "Display Ad 204--No Title," in New York Times, May 1, 1938, p. 171. The reduced price being about the equivalent of $\$ 7,048$ today is a reminder that travel was still only available to a limited number of Americans. «CPI Inflation Calculator» in Bureau of Labor Statistics, Washington, D.C., March 12, 2014, URL: < https://www.bls.gov/data/inflation_calculator.htm > [consulted June 23, 2018].

${ }^{29}$ «Vintage Menus-Children Party Menu, Cunard Line- R.M.S. Aquitania, 1924», in Gjenvick-Gjønvik Archives, Atlanta, GA, URL: < http://www.gjenvick.com/VintageMenus/ChildrenslMenus/1924-10-01ChildrensPartyMenu-Aquitania.html\#axzz4fSa7CwXw > [consulted April 27, 2017]; «Travel Brochures and Pamphlets- Steamships and Ocean Liners», in Gjenvick-Gjønvik Archives, Atlanta, GA, URL:

< http://www.gjenvick.com/HistoricalBrochures/index.html\#axzz4fSa7CwXw > [consulted April 27, 2017].

${ }^{30}$ A good example is "Travel Cruises and Tours: Thousands of Repeaters Making European Tours», in Los Angeles Times, March 26, 1939, p. C9. See also “Advertisement 3--No Title," in Forum and Century, 85, 5/1931, p. 1; “Advertisement 7--No Title," in Life, 96/1930, p. 27. See: COONS, Lorraine, VARIAS, Alexander, op. cit., pp. 137-180 for an extensive discussion on steamship companies and advertising.

31 «Pictures: Pic People Forget 'See America First,' as They Trek to Europe», in Variety, 114, 13/1934, p. 3. Articles titled «Americans in Europe» appeared throughout Variety in the 1920s. See also BUSBY, Marquis, "Lindbergh Record is Up-to-date: Flyer Followed in Travels By Camera; New Feature Comedy At Loew's», in Los Angeles Times, March 5, 1928, p. A7; KINGSLEY, Grace, «Mabel and Lew to Travel: Stars Plan Extended Trip in Europe During Summer...», in Los Angeles Times, April 23, 1927, p. A6. For an example of an article tracking everyday Americans see: CASS, Judith, "Vacations Call Chicagoans to Trips Abroad», in Chicago Daily Tribune, July 7, 1937, p. 17.

${ }^{32}$ Other clippings appear in Clara's diary on pages 172, 175, and 183.

${ }^{33}$ «Children to Travel to Berlin Alone: Aged Six and Four», in Chicago Daily Tribune, January 16, 1930, p. 3; "Good-Will Youth Land: American Girl Makes Appeal to British Youth at Plymouth», in New York Times, June 24, 1931, p. 4; «Youth Travels Around Globe on One Penny», in Chicago Sunday Tribune, December 2, 1934, p.
} 
and about young people also became popular in the 1930s and reading lists aimed at middle-class parents and educators regularly included them among their suggestions ${ }^{34}$. An example of this genre of travel literature is the book Around the World in Eleven Years. This was a travel account that twelve-year-old Patience Abbe and her brothers wrote, and it made the nonfiction bestsellers list of $1936^{35}$. Thus, travel to Europe was not only popular in publications aimed at middleclass adults, but also in publications specifically aimed at their children.

Image 1. Clara Schiefer Diary, Sept. 1, 1933, p. 244.

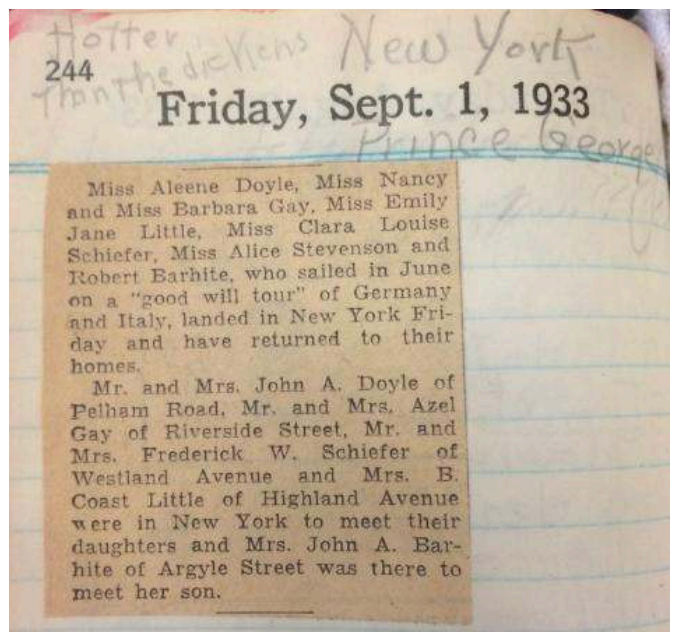

By the time the six Americans examined in this article embarked on their trips, youth travel to Europe was highly visible in the publications middle-class Americans of all ages read. While no single diary entry or letter excerpt can be read as representative of American youth in general, the travel writing of these young Americans shows how a group of individuals participated in and

5; «Youth Groups Try Out International Living: College Student Tells Daily Doings at Home and Afield With Europeans», in Los Angeles Times, September 27, 1936, p. 9; "Youth Earns and Learns Traveling Globe», in Washington Post, April 17, 1938, p. 2; CHRISTENSEN, C., «The Voice of the Traveler: Youth Hostels Again», in Chicago Daily Tribune, May 22, 1938, p. 9; JACKSON, Arnold, "Accent on Youth: (European Plan)», in Los Angeles Times, March 19, 1939, pp. 5, 8; «Youth Hostels Grow: The Hiker With Knapsack Now Becoming World Traveler», in New York Times, February 26, 1939, p. 142.

${ }^{34}$ Book lists and recommendations for adults often included travel literature. For travel literature aimed at or specifically about children see, for example: «Travel for Tots» in Chicago Daily Tribune, November 14, 1925; DALGLIESH, Alice, «Books for Children: Travel at Home» in Parents' Magazine, 11, 7/1927, pp. 42-44; «A Roosevelt Family Tours the Balkans», in New York Times Book Review, June 23, 1935, p. 10; LECRON, Helen Cowles, «Books That Make School Studies Live: Here Are Fiction, History, and Travel Volumes Which Will Stimulate Your Children's Interest Unbelievably», in Better Homes and Gardens, 9, 1/1930, pp. 31, 59; EATON, Anne T., «Books for Children: Ocean Travel», in New York Times, December 20, 1931, p. 9; LYNCH, Maude Dutton, «Story Book Sets For Children», in Parents' Magazine, 6, 11/1931, pp. 22-23, 87.

${ }^{35}$ See: ABBE, Patience, Richard Abbe, and John Abbe, Around the World in Eleven Years, New York, Frederick A. Stokes Company, 1936; «Children's Travel Book Becomes Best Seller», in Chicago Daily Tribune, May 16, 1936, p. 10; BURT, Daniel S., The Chronology of American Literature, Boston, Houghton Mifflin, 2004; VITELLO, Paul, «Patience Abbe, Child Chronicler of Travels, Dies at 87», in The New York Times, March 31, 2012, URL:

< https://www.nytimes.com/2012/04/01/arts/patience-abbe-87-child-chronicler-of-travels-is-dead.html > [consulted June 27, 2018]. 
helped to produce this culture of travel. Passenger lists indicate that the youths had not previously crossed the Atlantic and many of them asserted in their writing that this was the first time they left the country ${ }^{36}$. Their trips were then the first time these young Americans encountered foreigners and fellow Americans beyond the borders of the U.S. As scholars who study travel literature recognize, through writing, tourists negotiated both the meaning of "home" and explored the United States' role on the international stage. The youth studied here were no exception-through their writing they re-evaluated their Americanness in an international framework ${ }^{37}$. But while their contemporary adults who encouraged travel saw it as a way to teach American youth to be good citizens and emphasized the cultural appreciation that could come through travel, turning to the actual youths' writing shows how they made sense of their trips in ways unacknowledged in the prescriptive literature back home.

\section{Dancing, Dating, and Drinking: Youth Culture in the Travel Writing of}

\section{Young Americans in Europe, 1929-1937}

Though the individuals who wrote the travel writing examined in the rest of this article hailed from different areas of the U.S., the similarities between their writing allow for them to be studied as a group that together demonstrates, in Kelly Schrum's terms, "a distinct teenage culture in the making» ${ }^{38}$. The 1920 s and 1930 s were particularly important decades for the consolidation of an identity around being young, especially for middle-class American young women in their teens. As American youths spent an increasing amount of time outside the home, surrounded by people their age and advertisements targeted youths - especially young women as a specific consumer group, «peer groups» came to compete with the role of the family as one of the "primary units of affiliation» that «fulfilled individual emotional needs for security and identity» ${ }^{39}$. At the same time, sex became rapidly visible as American society moved toward what John D'Emilio and Estelle Freedman characterize as «sexual liberalism» that separated sexual activities from the goal of reproduction and promoted individual sexual satisfaction as a key

\footnotetext{
36 “New York Passenger Lists, 1820-1957," New York, NY, 18 Aug. 1929, Scanned Image, Ancestry.com Roll 4557, Line: 26, Page: 209 (Anna Bob Taylor); and 22 Aug. 1930, Scanned Image, Ancestry.com Roll 4804, Line: 23, Page: 111 (Yvonne Blue); and 1 Sept. 1933, Scanned Image, Ancestry.com Roll 5381, Line: 23, Page: 70 (Clara Louise Schiefer); and 12 Feb. 1936, Scanned Image, Ancestry.com Roll 5763, Line: 6, Page: 7 (Victoria Brown); and 21 Sept. 1936, Scanned Image, Ancestry.com Roll 5872, Line: 4, Page: 126 (Eleanor Winograd); and 14 Sept. 1937, Scanned Image, Ancestry.com Roll 6045, Line: 23, Page: 19 (Rosalie Jones). All consulted March 3, 2017.

${ }^{37}$ ENDY, Christopher, op. cit., p. 565; SCHRIBER, Suzanne Mary, op. cit., p. 9.

${ }^{38}$ SCHRUM, Kelly, op. cit., p. 10. Eleanor did turn twenty years old while in Poland, but the writing examined here is from when she was nineteen. Moreover, numerical age was not as important as an identification with being young.

${ }^{39}$ See: SCHRUM, Kelly, op. cit., p. 12 (quotes); BAILEY, Beth, op. cit., p. 78.
} 
aspect of both marriage and individual happiness ${ }^{40}$. New technologies, from movies to massproduced magazines and newspapers, commercialized and legitimized images of women who were more sexual and pleasure-seeking than their counterparts from preceding generations. As «sex and sexuality increasingly entered the public sphere» they «became part of the very definition of youth ${ }^{41}$. Like other Americans in their teens who kept diaries during the interwar years, the importance of both age and gender for how these youths understood themselves as individuals and as part of a group is clear in their travel writing ${ }^{42}$.

What makes their writing distinct is that it was kept beyond the borders of the U.S. and thus shows how age and gender were important for how these youths made sense of whom and what they encountered as they traveled. In other words, their experiences as young women in their teens growing up in a period in which anxieties about youth, gender, and sexuality were high in the U.S. informed their "tourist gaze»" ${ }^{43}$. They made sense of their trips by contrasting what they encountered abroad to the social and political norms with which they were familiar at home. For these young Americans, coming to terms with what it meant to "be American" while abroad was in part defined by participating in what were deemed controversial youth habits back in the U.S. activities that the adults, educators, and reformers writing the articles in middle-class publications did not anticipate when they encouraged youth travel ${ }^{44}$.

Though the youths acknowledged that parts of their journey did not live up to the luxurious image of travel projected in movies and advertisements, their writing confirms the importance of the «congenial people» the advertisements emphasized. Their journal entries indicate that, for them, these people were often young people from around the world. Comparing passenger lists of the ships that Victoria, Clara, Anna, Rosalie, Yvonne, and Eleanor took shows that they, along with their fellow travel companions in their teens, were among the youngest onboard the ships and part of a minority of passengers that were under twenty years old. Nonetheless, there was a vibrant youth culture scene made up of Americans, Europeans, and others during the voyages in

\footnotetext{
${ }^{40}$ D’EMILIO, John, op. cit., p. 241.

${ }^{41}$ BAILEY, Beth, op. cit., p. 77.

${ }^{42}$ I come to this conclusion through my own research with American youth diaries in the 1920s and 1930 s. See also: SCHRUM, Kelly, op. cit.; BAILEY, Beth, op. cit.

${ }^{43}$ John Urry explains that one's tourist gaze «varies by society, by social group and by historical period» and is "constructed through difference». "What makes a particular tourist gaze depends upon what it is contrasted with; what the forms of non-tourist experience happen to be. The gaze therefore presupposes a system of social activities and signs which locate the particular tourist practices, not in terms of some intrinsic characteristics, but through the contrasts implied with non-tourist social practices». URRY, John, The Tourist Gaze: Leisure and Travel in Contemporary Societies, London, SAGE Publications, 1990, pp. 1-2.

${ }^{44}$ While previous scholarship has asserted that Americans used their experiences abroad «to contemplate their own attitudes about gender roles and sexuality», studying youth travel writing nuances this scholarship and indicates that, particularly for youth, coming to terms with what it mean to «be American» while abroad, meant an exploration of issues specifically related to American youth culture. BLOWER, Brooke, op. cit., p. 153.
} 
which they participated ${ }^{45}$. While passenger lists indicate that some of the people the youths wrote about were under twenty years old, the term "youth culture» as it is used here is informed by the youths' writing - they often referred to those they wrote about while on the ship as, for example, «boys», distinguishing their peers from adults whom they described as «men» ${ }^{46}$.

Other entries reveal an attention to their own and their peers' age. Both Yvonne and Anna gave special attention in their diaries to their ability to enter the Casino at Monte-Carlo. Yvonne wrote, «No one under 21 is supposed to be admitted, but [Bebia?] managed it somehow and we all got it $»^{47}$. Anna offered a similar account: «People under twenty-one are not supposed to get in but I got by but Boliver and Fred couldn't and their [sic] seventeen ${ }^{48}$. Victoria and Clara also included the ages of those they met in their travel writing. Clara specified that «2 German girls (14 yrs) live across the street» during her time in Hamburg and again specified the ages of the students she met (seventeen, twelve, and fifteen) while visiting a school in Altena ${ }^{49}$. Likewise, Victoria wrote after spending time with her father's friend's family, «He had with him his two daughters $13 \&$ $15 »^{50}$. Clara and Victoria's decision to highlight this detail, over other characteristics of those they were describing, suggests the importance of age to the youths. The knowledge of their peers' age might even indicate a verbal inquiry (perhaps in a second language, in the case of Clara's neighbors across the street) and discussion among the young people about their age. Even when they did not specifically refer to age in numbers, they often specified when those they met were their own age or used the adjective "young" to describe their peers. Instances in which the youths recorded their peers' ages or more abstractly referred to their peers in ways that set them apart from other generations highlight that the youths took their identification with a specific youth peer culture abroad with them. While young people traveling before the interwar period surely identified with those their age, the youths examined here often privileged this characteristic as opposed to other characteristics, such as nationality, when describing the people they met suggesting the importance of a generational identity around being young for these American youths.

How some of the youths wrote about their interactions with other young people reveals that in these interactions the youths participated in activities that were deemed controversial youth habits in the U.S.: dancing, dating, and drinking. By participating in these activities, Anna,

\footnotetext{
${ }^{45}$ RENNELLA, Mark, WALTON, Whitney, «Planned Serendipity: American Travelers and the Transatlantic Voyage in the Nineteenth and Twentieth Centuries», in Journal of Social History, 38, 2/2004, pp. 365-383.

${ }^{46}$ A survey of the ages of the passengers on board the ships suggests that most passengers were in their twenties and thirties. Exact age appeared less important than an identification with a fellow passenger as being "young" to the youth examined here. See footnote 36 for the passenger lists.

${ }^{47}$ Yvonne Blue Travel Diary, Aug. 10, 1930, pp. 111.

${ }^{48}$ Anna Taylor Diary, July 13, 1929.

${ }^{49}$ Clara Schiefer Diary, July 17, 1933, pp. 198; and July 25, 1933, pp. 206.

${ }^{50}$ Victoria Brown Travel Diary, October 25, 1935, Part III, p. 8.
} 
Victoria, Clara, and Yvonne challenged prevailing white, middle-class gender and sexual norms in the U.S. at this time. At the beginning of the twentieth century, courtship rapidly gave way to dating as emphasis was put on romantic love and companionship. Additionally, the recent availability of heterosocial leisure spaces, like the cinema and dance hall, provided places in which youths could socialize outside the confines of the home. The activities associated with dating separated youths from previous generations. For example, petting and necking (intimate touching that went beyond kissing but did not include sexual intercourse) became an «initiatory stage» to the "coital experience of adulthood», previously unacknowledged by older generations ${ }^{51}$. Likewise, youths saw their most popular pastime, dancing, as one of their least scandalous activities. Yet this youth view of dancing was in stark contrast to the opinions of adults who deemed the youths' dancing habits as permitting too much movement and contact, and especially promiscuous behavior for girls and young women. Anna explained the different generational perspectives of dancing when she wrote, «Tonite we all sat on the top deck and danced with old papa's [sic] who know nothing about dancing $»^{52}$. These new forms of sociability, from simple exchanges in heterosocial spaces to more intimate interactions between boys and girls in private, were «part and parcel» of American youth identification and constituted «a crucial site of [individual] identity construction $»^{53}$. Since sexuality was a defining aspect of and controversial issue for American youths, instances in which the youths wrote about heterosocial interactions shows that traveling opened space for them to explore their own sexual selves in ways that might not have been possible at home ${ }^{54}$.

As Anna's entry suggests, dancing was a popular pastime on the ships. On one of her first nights aboard the S.S. Champlain Victoria described noticing a «very nice-looking boy» who finally asked her to dance ${ }^{55}$. Throughout the rest of the journey, Victoria recorded her time with the boy, Richard, and particularly emphasized the fun they had as they danced «with the ship rolling and rocking $»^{56}$. Dancing with Richard became a defining aspect of Victoria's trip across the Atlantic

\footnotetext{
${ }^{51}$ D’EMILIO, John, op. cit., pp. 256, 258. Beth Bailey provides the most comprehensive study of courtship and dating in From Front Porch to Back Seat.

${ }^{52}$ Anna Taylor Diary, June 29, 1929.

${ }^{53}$ D’EMILIO, John, op. cit., p. 256.

${ }^{54}$ For the purpose of this paper I am defining "sexuality" as "desires, relationships, acts, and identities concerned with sexual behavior». While this definition of sexuality comes from: CLARK, Anna, Desire: A History of European Sexuality, New York, Routledge, 2008, p. 3; it is no less applicable to sexuality in the U.S. Scholars who study sexuality in the U.S. also define and study it using these terms. Their definitions, however, are not as succinct. I knowingly offer an often-simplified discussion of sexuality and politics in Europe, let alone the individual countries of Europe, and a one-sided view of the exchanges between the young women and the Europeans they met. I focus on how the young women explored their sexuality within the specific context of sexuality in the United States at this time.

${ }^{55}$ Victoria Brown Diary, Aug. 18, 1935, Part I, p. 72.

${ }^{56}$ Ibidem, Aug. 18, 1935, Part I, pp. 73-74; Aug. 21, 1935, Part I, pp. 79-80; and Aug. 22, 1935, Part I, pp. 83. In their study of steamship travel, Lorraine Coons and Alexander Varias argue, «ship life was pure escapism for both passengers and crew. On board, a passenger could let down his guard». Their study also reveals
} 
and she wrote about the opportunities to dance on the ship in overwhelmingly positive terms. Clara, on the other hand, became keenly aware of her inability to dance and how it inhibited her from socializing with her peers ${ }^{57}$. Once back in the U.S., Clara immediately began private dance lessons and «Learn to dance» was her most heavily underlined New Year's resolution ${ }^{58}$. Clara's desire to dance once back in the U.S., inspired by her trip to Europe, points to one way her experiences traveling influenced her even on her return home.

Dancing was also part of a culture of dating that took place as the youths traveled. As Beth Bailey argues, by the mid-1920s "dating" was the popular form of courtship for American youth and was characterized by a competition for who could have the most and greatest variety of dates $^{59}$. While Victoria only wrote about one boy in particular, Anna captured this new form of courtship - a style of courtship that she took with her even as she left the shores of the U.S. - in her writing. Anna described one afternoon, «had six boys with me...[T]hey all fed me tea and cakes and I had a great time» and wrote another night that she «had a date with Henry and 3 couples of us: Holland and Gordon, Hennrietta and Bunny, and Henry and $I »^{60}$. While we cannot know where these youths were from, as Anna did not provide last names, it is possible that these were not all American youth.

Not only did a culture of dating occur on the ships, other entries reveal that it continued as the youths traveled throughout Europe. Anna chronicled her friend Holland's «darling Italian aviator beau» and their exchange of pictures during her time in Italy and, while in Germany, Yvonne wrote about an experience going on a date with her friend and "two Alpine fellows ${ }^{61}$. The four had their pictures taken at a photomaton and then went to a dance hall (see Images 2 and 3). Clara also wrote about the relationship her friend, Isabel, had while she was in Germany and recorded her own encounters with young men: «I stray from the group...About 4 I go for a walk with a Josef?? [sic]...Heavens only knows why. Return and find that the 'German-American' club had taken the others to a beergarten $\left[\right.$ sic] to dance $»^{62}$. This excerpt indicates that Clara saw her walk with Josef - a German - significant enough to write in her diary and the question marks after his name suggest that she might not have known him well. As Clara's travel writing was part of a year-long diary she kept, what is interesting about this passage is that she did not write similar

«women outnumbered men two to one in all classes». See COONS, Lorraine, VARIAS, Alexander, op. cit., pp. $50,32$.

${ }^{57}$ For Clara writing about dancing on the ship, see Clara Schiefer Diary, Aug. 25, 1933, p. 237; Aug. 24, p. 236, 1933; Aug. 27, p. 239

${ }^{58}$ Clara Schiefer Diary, Dec. 13, 1933, p. 347; Memoranda, p. 366.

${ }^{59}$ BAILEY, Beth, «From Front Porch to Back Seat: A History of the Date», in Magazine of History, 18, 4/2004, pp. 23-26, p. 23.

${ }^{60}$ Anna Taylor Diary, Aug. 15, 1929.

${ }^{61}$ Ibidem, July 9 and 19, 1929. Yvonne Blue Travel Diary, July 24, 1930, pp. 66-69.

${ }^{62}$ Clara Schiefer Diary, July 24, 1933, p. 205. Clara explicitly indicated that Josef was German by explaining that he took her to visit his school. For Clara's attention to Isabel and Monroe, see Clara Schiefer Dairy, Aug. 11, 1933, p. 223. 
excerpts before her trip. Whether she chose not to write about them back in the U.S. because she was afraid someone might read her diary, or she did not have similar experiences at home, Clara increasingly recorded her interactions with young men throughout her diary, which indicates that travel allowed for interactions among youths and made her feel comfortable enough to record them.
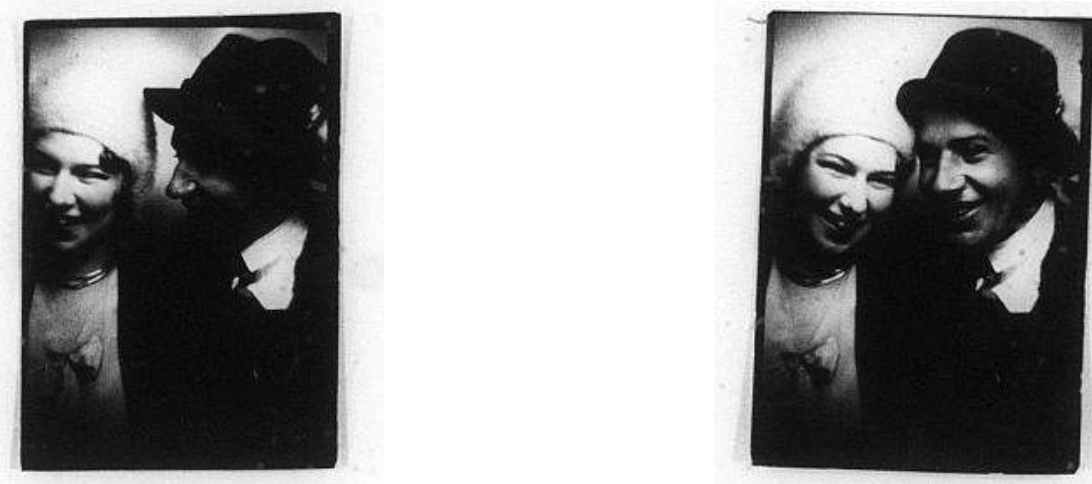

Images 2 and 3.

Yvonne described the photos: "Charles wrote on the back of one of mine in German and wouldn't translate it". Yvonne Blue Travel Diary, July 24, 1930, p. 67.

Writing about drinking in some capacity - whether it be drinking with their peer groups on board the ships, going to beer gardens in Germany, or tasting champagne for the first time - was also common throughout many of the youths' writing. As the sale of alcohol was constitutionally banned in the U.S. between 1920 and 1933 under Prohibition, moments in the youths' writing when they wrote about drinking demonstrate one way in which travel challenged their understanding of cultural norms (or frameworks of licit and illicit behaviors) in the U.S. «Breaking the law» on alcohol consumption back home was understood by reformers as a «malecentered problem», especially among youth ${ }^{63}$. Thus, consuming alcohol while they traveled was not only significant in that they were participating in something that was illegal in the U.S. if they were writing during Prohibition, but also engaging in behavior that was typed as masculine.

As Yvonne and Anna specifically wrote during Prohibition, their diary entries provide the best examples of how the availability of alcohol abroad likely made the youths think about what they were familiar with in the U.S. For example, Yvonne offered a detailed description of a night after «six glasses" of «good sweet wine» that made her feel «dizzy» and quite «sick» (emphasis in original $)^{64}$. Anna's entries are particularly telling because, like Clara, she kept her diary over the course of the entire year and we can thus compare the entries she wrote while traveling to entries

\footnotetext{
${ }^{63}$ For a discussion of American tourists and Prohibition see: LEVENSTEIN, Harvey, op. cit., p. 241; BLOWER, Brooke, op. cit., pp. 107-108, 152; GREEN, Nancy, op. cit., p. 156. For information on youth culture and Prohibition see: FASS, Paula, op. cit., p. 310 (quote).

${ }^{64}$ Yvonne Blue Travel Diary, July 24, 1930, pp. 75-77.
} 
she wrote before her trip. Before leaving for Europe Anna disapprovingly commented on the young man she liked getting «tight», or drunk, at a dance ${ }^{65}$. Similarly, on the second night aboard the ship on her journey to Europe, Anna wrote, «This is an English boat we're on and babe are some of the people getting tight. Whew! ${ }^{66}$ Though Anna did not in this passage explicitly criticize people for drinking, she did distance herself - and the U.S. - from the activity by specifying that the boat was «English». Yet, as she continued her trip she humorously described members of her travel party being drunk and experimented with alcohol herself, as on the last night of her trip when she was with the three couples mentioned above: "we split a bottle of champagne to celebrate the last night out ${ }^{67}$. Writing about drinking in a positive manner only came after Anna was abroad. This might indicate that as she traveled she became more comfortable with habits unfamiliar to her. Since alcohol was prohibited in the U.S., these youths' attention and access to it offers a concrete example of how travel to and in Europe differed from the American context they left.

These are just a few examples of how the youths interacted with other young people, including Europeans, in activities deemed controversial youth habits in the U.S. Overall, the attention to such topics throughout these youths' writing demonstrates that these American youths and their travel companions deemed socializing with boys and men and the availability of alcohol noteworthy parts of their trips. As contentious activities back in the U.S., pursuing these activities indicates one way the youth's understanding of themselves in terms of their age and gender back home shaped their experience abroad. Though the youths' writing about dancing, dating, and drinking only offers the perspectives of these young Americans, the various people the youths wrote about indicate that they did not pursue these activities alone, but with a variety of peers on the ships that crossed the Atlantic and in towns and cities throughout Europe. Though scholarship on the transfer of youth culture between the U.S. and Europe tends to focus on media, such as music and movies, as facilitating this exchange the writing of these six Americans at least indicates that a more personal exchange occurred between this small sample of Americans and European youths ${ }^{68}$. Moreover, during these social exchanges the American youths participated in activities that were often disapproved of - if not downright illegal - back home. Travel thus

\footnotetext{
${ }^{65}$ Anna Taylor Diary, May 18, 1929.

${ }^{66}$ Ibidem, June 30, 1929.

${ }^{67}$ Ibidem, Aug. 17, 1929.

${ }^{68}$ For scholarship on the transfer of youth culture between the U.S. and Europe, see HORN, Adrian, Juke Box Britain: Americanisation and Youth Culture, 1945-60, Manchester, Manchester UP, 2009; POIGER, Uta G., Jazz, Rock, and Rebels: Cold War Politics and American Culture in a Divided Germany, Berkeley, University of California Press, 2000; and SCHILDT, Axel, SIEGFRIED, Detlef (eds.), Between Marx and Coca-Cola: Youth Cultures in Changing European Societies, 1960-1980, New York, Berghahn Books, 2006. As these titles indicate, this scholarship overwhelmingly concentrates on the post-1945 period.
} 
offered these young Americans the opportunity to participate in activities that would have been socially transgressive back home, especially for young women their age.

\section{4. "We find it very thrilling to be here at such an exciting period": Political Issues in the Youth Travel Writing}

Though many of these young Americans gave a fair amount of attention to topics seen as characteristic and often controversial habits of young people in the U.S., they also engaged with what could be called "political issues" while they were abroad". By "political issues" I mean topics related to governmental actions and the impact of these actions on everyday life. I mean to use political issues in contrast to how the youths' contemporaries and subsequent scholarship have painted the group as almost exclusively interested in their immediate peer cultures and popular culture. Though interested in these topics, the young Americans examined here were also aware of and talking about political issues with their family members and peers in international spaces. This was especially true for fourteen-year-old Victoria, sixteen-year-old Rosalie, and nineteenyear-old Eleanor. As these three traveled from 1935 to 1937, change over time is detectable in the travel writing. As the 1930s progressed, the young Americans gave more attention in their travel writing to political issues. Turning to rich moments in these three youths' writing shows how, on the one hand, their writing reflects the opinion of their contemporaries back home who linked national and international consciousness and, on the other, how gender and age were important for how young people came to terms with the differences between their home country and the countries they visited.

Rosalie - who traveled with her father and dedicated her travel journal to him, which suggests he might have read it - did not record interactions with the boys and men she met like the youths in the previous section, but she did write about the politics and gender norms of the countries she visited. She thus engaged with the dominant middle-class gender and sexual norms in the U.S. by removing herself from the situations she wrote about and making comparisons between her home country and the countries she visited. For example, while traveling in Soviet Russia, Rosalie wrote:

\footnotetext{
${ }^{69}$ Studies of American youth perpetuate a characterization of this group as only interested in peer culture and popular culture by concentrating on these topics. The travel writing examined here complicates this characterization. See FASS, op. cit., pp. 18-20 and Chapter Eight for a description of the apolitical nature of youth. Whitney Walton pushes back against this characterization in her study of the Junior Year Abroad. See WALTON, Whitney, «Internationalism and the Junior Year Abroad», cit., p. 271.
} 
No effort is made to segregate men and women travellers [sic]. A travelling acquaintance of ours, a young lawyer from Amsterdam, was horrified last night when he was obliged to share his sleeping compartment with a Russian bride...The Russian boast that they are modern and broad-minded about such things! 'Amazingly so!', we think ${ }^{70}$.

Four days later, Rosalie's father bought all of the berths in their sleeping car because, as Rosalie emphasized again, "on Russian trains men and women are put together in the same compartment to spend the night ${ }^{71}$. In her acknowledgement that «the Russians boast that they are modern and broad-minded about such things», it is clear that Rosalie was aware of the different attitudes toward and positions of women in Soviet Russia, especially in the images propagated by the government of a commitment to women's equality ${ }^{72}$. In her declaration of «'Amazingly so!' we think» Rosalie directly engaged with the status of women in Soviet Russia in a way that suggests she disapproved of having men and women in the same sleeping quarters. However, consideration must be paid to the fact that Rosalie was traveling with her father and it was he who upheld the dominant gender norms in the U.S. by buying the entire sleeping car for her. Though not explicitly recorded in her writing, it would not be too much to presume that Rosalie compared the situation in Soviet Russia to her own experience in the U.S. and other European countries. Once exposed to these issues, she likely continued to reflect on them back home.

On the other end of the political spectrum, in Italy, both Rosalie and Victoria wrote about experiencing public displays of fascism that were quite different from anything they were used to in the U.S. Rosalie wrote after visiting the Forum of Mussolini, «Daddy became very hot and bothered over Fascism and wouldn't even let me buy any pictures of Mussolini's monuments to himself $»^{73}$. Likewise, after seeing soldiers running with guns, Victoria recorded that her family wondered «if [the soldiers] were getting ready for Absinnia [sic]. The people don't seem to be worrying about war though. We find it very thrilling to be here at such an exciting period $»^{74}$. Both passages capture some of the anxiety in the U.S. surrounding rising fascism ${ }^{75}$. Rosalie's father clearly did not agree with it, prohibiting her from even buying a souvenir, and though Victoria

\footnotetext{
${ }^{70}$ Rosalie McLeod Diary, June 29, 1937, pp. 9. Rosalie again commented on gender roles while in Istanbul. See Rosalie McLeod Diary, July 8, 1937, pp. 13-14.

${ }^{71}$ Rosalie McLeod Diary, July 3, 1937, pp. 11

${ }^{72}$ For information on sexuality and gender in Soviet Russia see «Managing desire or consuming sex in interwar culture» and especially «Sex and the state in the 1930s: Sweden, the Soviet Union, and Nazi Germany» in CLARK, Anna, op. cit., pp. 162-197; WOOD, Elizabeth A., "The Trial of the New Woman: Citizensin-Training in the New Soviet Republic», in Gender and History, 31, 3/2001, pp. 524-545.

${ }^{73}$ Rosalie McLeod Diary, Aug. 2, 1937, pp. 29.

${ }^{74}$ Victoria Brown Travel Diary, Sept. 18-Sept 20, 1935, Part II, pp. 8-9.

${ }^{75}$ KATZNELSON, Ira, Fear Itself: The New Deal and The Origins of Our Time, New York, W.W. Norton and Company, 2013.
} 
did not specifically say this, her passage suggests that the family might be concerned by the threat of war. Nonetheless, the monuments and presence of soldiers throughout Rome intrigued Rosalie and Victoria and they offered detailed descriptions of what they observed.

The sustained attention in both writing and drawings fourteen-year-old Victoria gave to the visibility of uniforms, public rallies, flags, and banners demonstrates that she consciously or unconsciously grappled with the political atmosphere she experienced in Italy through her travel writing. A few weeks after the entry above, Victoria recorded: «When mummy brought the paper back we saw that the Italians had captured Adua!! (Adowa) [sic]». Her family then went out and observed the city decorated «with flags to celebrate the victory» and «Adua e nostra! » (Adowa is ours) written on walls ${ }^{76}$. Surrounding the entry Victoria included colored drawings of flags and sayings like «Viva Il Duce» (see Images 4 and 5). Such drawings were common throughout her travel diary (see Images 6 and 7). As these entries indicate, Victoria-and the other youths-often incorporated foreign languages in their writing. This usually involved the inclusion of short phrases and sometimes consistently writing the date of their entries in German, French, or Italian. Writing in a foreign language was thus one way these young women engaged with the cultures they traveled in on their own terms ${ }^{77}$. Victoria also offered a detailed description of a fascist rally she heard Mussolini speak at. Her written description of the event included how «thrilling» it was to see Mussolini speak, hearing the crowd shouting «Duce! Duce!» and seeing "girl fascists march past» that "were all sizes from tiny little girls to grown women» ${ }^{78}$. Other than writing that she and her family found it «thrilling» to be in Italy and to observe these mass spectacles, Victoria offered no personal commentary on how these public political displays made her feel, perhaps suggesting that she saw herself not as a participant, but only as an observer ${ }^{79}$.

\footnotetext{
${ }^{76}$ Victoria Brown Travel Diary, Oct. 7, 1935, Part II, pp. 85.

${ }^{77}$ A few good examples are: Anna Taylor Diary, July 9, 1929; and Yvonne Blue Travel Diary, Aug. 10, 1930, pp. 104. Scholarship on travel literature asserts that incorporating language is one way to gauge a tourist's perception of a culture. Additionally, scholarship on American youth culture acknowledges that youth in the early twentieth century often changed their handwriting as a way to self-consciously experiment with their identity. Read together, these scholarships indicate that these young women used foreign languages in their writing as a means to engage the cultures they encountered on their own terms and experiment with their identities. BRUMBERG, Joan, op. cit., pp. 104, 234. Brumberg comes to this conclusion through interviews. See also LUBRICH, Oliver, Travels in the Reich, Foreign Authors Report from Germany, 1933-1956, Chicago, University of Chicago Press, 2012, p. 14.

${ }^{78}$ Victoria Brown Travel Diary, Oct.2, 1935, Part II, pp. 51-61.

${ }^{79}$ Scholars who have studied how foreign visitors reacted to similar mass spectacles in Nazi Germany have noted that «[b]y reflecting upon these mass demonstrations, the individual traveler can set himself [or herself] apart from the anonymous collective mass of Germans, and assert his [or her] own identity in the foreign country». LUBRICH, Oliver, op. cit., p. 13.
} 


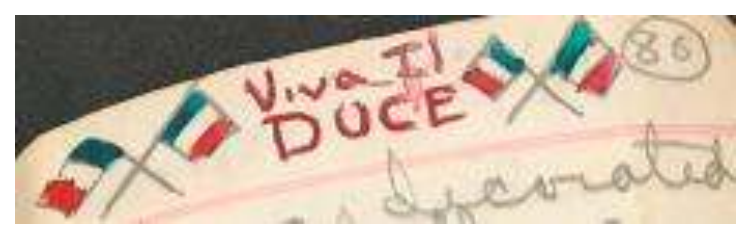

Image 4. Victoria Brown Travel Diary, Oct. 7, 1935, Part II, p. 86.

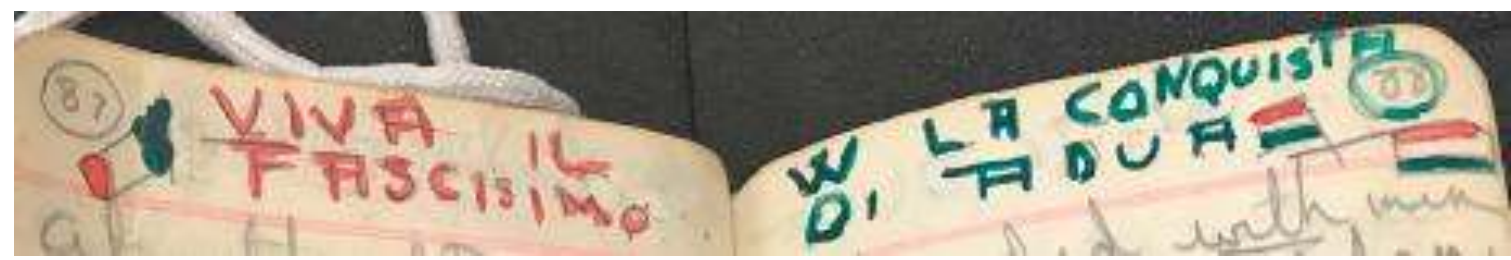

Image 5. Victoria Brown Travel Diary, Oct. 7, 1935, Part II, pp. 87-88.
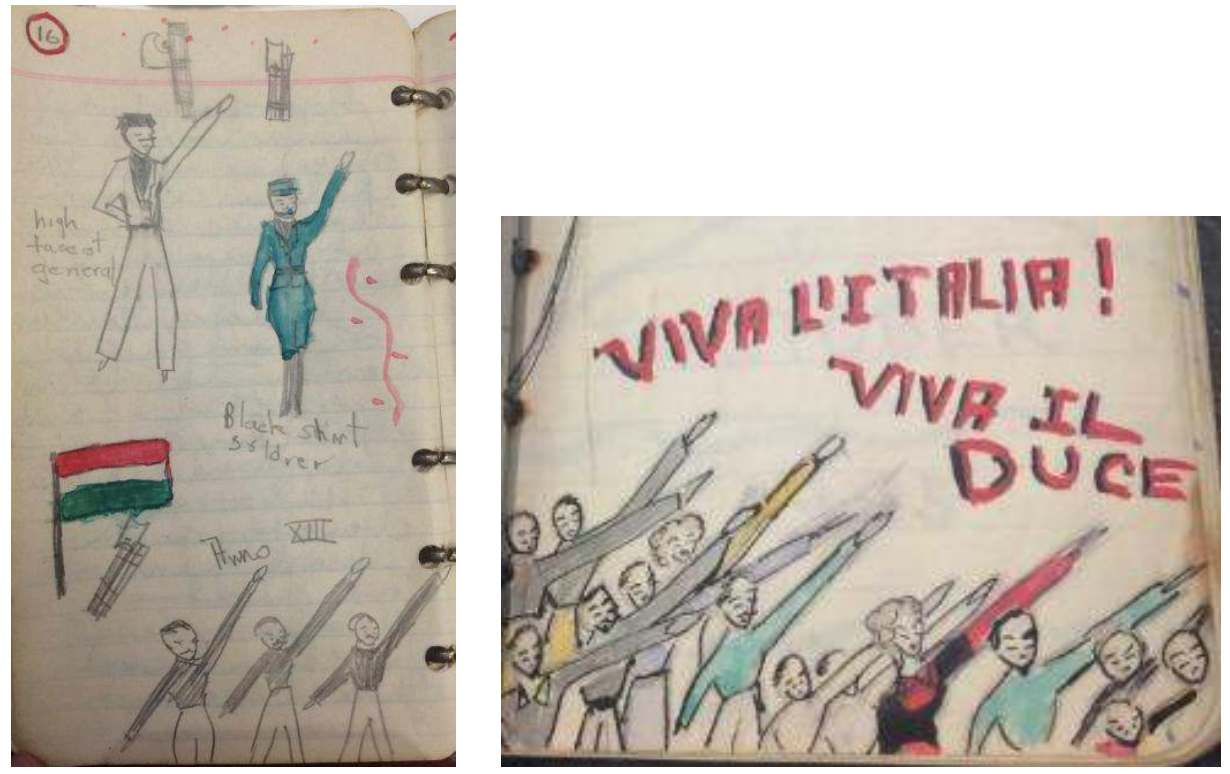

Images 6 and 7. Victoria Brown Travel Diary, Sept. 21 and N/D, 1935, Part II, pp. 16 and 182. These are only a few examples of Victoria's drawings.

Not only did the mass spectacle of the public rally intrigue Victoria, but particularly the participation of «little girls to grown women». She was so intrigued that she specified that «[t]hey were dressed like this» and included a drawing (see Image 8) ${ }^{80}$. Victoria frequently emphasized the "young" fascists she saw and often wrote about or drew the clothing they wore. This was true for both young women and young men. For example, one excerpt indicates that she was surprised to see a group of boys dressed as Italian soldiers: «we saw some Italian boy scouts who were too cunning. They dress them up in black shirts and caps even them»" The clarification «even them» captures that Victoria found the inclusion of young people, likely her own age, surprising. To be sure, the Boy Scouts were suppressed under fascism and thus it is unlikely that this was actually a

\footnotetext{
${ }^{80}$ Victoria Brown Travel Diary, Oct. 2, 1935, Part II, pp. 51-61.

${ }^{81}$ Ibidem, Sept. 28, 1935, Part II, pp. 39-40.
} 
group of Boy Scouts. ${ }^{82}$ Rather, upon seeing a group of young uniformed boys, Victoria compared them to what was most familiar to her in the U.S. The emphasis Victoria placed on the age and gender of the Italians suggests that the participation of youth and women in Italian politics interested her. Given her own age and gender, perhaps she even found this participation appealing.

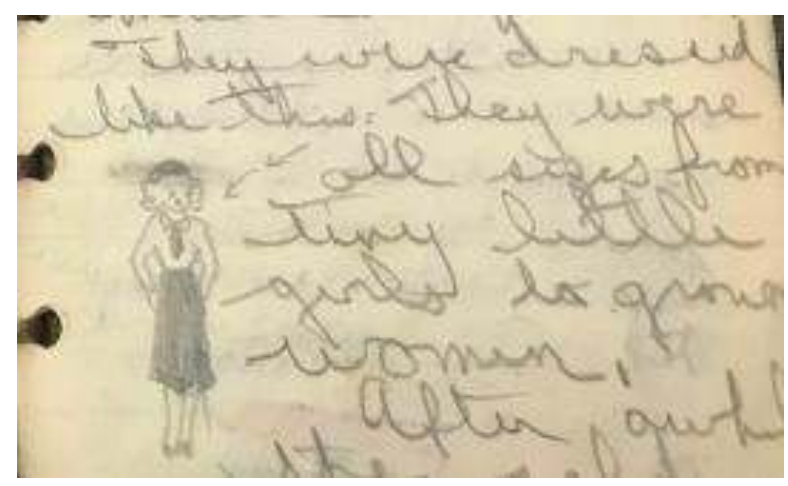

Image 8. Victoria Brown Travel Diary, Oct. 2, 1935, Part II, p. 60.

Compared to the other youth, Eleanor engaged with political issues and included her own political opinions the most. The fact that she was Jewish and visiting her Jewish relatives in Soviet Russia and Poland likely contributed to her awareness of political issues ${ }^{83}$. That said, age was no less important to how Eleanor engaged with politics in her travel writing. Passages from her writing indicate that the discussions Eleanor had with her family were often with family members her own age and revolved around economic and political issues in the U.S. and Europe. In Soviet Russia, Eleanor and her father's cousin's children discussed various topics, from anti-religious propaganda to college tuition in the U.S., Russian student wages, and American unemployment: «The young people said they knew we had high unemployment in the U.S. and that such a thing could never happen under their system $»^{84}$. Similarly, in Poland, she described talking to a cousin her age:

Motek and I sit on the balcony sometimes and listen to music...Sometimes we keep the music quietly [sic] and discuss - one might say argue - mostly politics. He is very cynical for someone

\footnotetext{
${ }^{82}$ GORI, Gigliola, Italian Fascism and the Female Body, London, Routledge, 2016, p. 3.

${ }^{83}$ Before visiting her family, Eleanor traveled with a socialist student group, the Student League for Industrial Democracy. She acted as the secretary of this group at home. Though in the travel writing examined here she did not write about this experience, this is further evidence of her political involvement. See Oral History Interview with Eleanor Judd, 1984 February 21. Rocky Mountain Jewish Historical Society Oral Histories, B098.01.0005.00123. Beck Archives of Rocky Mountain Jewish History, Special Collections, University of Denver, URL: < https://duarchives.coalliance.org/repositories/2/digital_objects/9913 > [consulted June 29, 2018]. Eleanor was the last Jewish-American member of her family to visit pre-World War Two Europe.

${ }^{84}$ Eleanor Winograd Travel Writing Transcript, Aug. 1, 1936, p. 2.
} 
so young. He is just my age...He says, 'the New Deal and Roosevelt will help America but America needs help less than any other country.' I could certainly state my views better in English, and he says he would win all the arguments if I only understood Polish ${ }^{85}$.

These passages show how Eleanor grappled with her family's preconceived notions of the U.S. and how conversations she had in Europe encouraged comparisons between the U.S. and other countries. On confronting Motek's views of the U.S., Eleanor felt the need to defend her home country. Moreover, each of these conversations occurred between young people. They compared and contrasted the experiences of those around their age in both of their countries and Eleanor's writing gives the impression that they concluded that their experiences-both personal and overall experiences living under different forms of government-were quite different. Nonetheless, the fact that they were young and, in the case of Motek and Eleanor, had a shared generational interest (music) seemed to bring them together. These conversations are prime examples of how Eleanor's understanding of her Americanness was not just constructed within the borders of the U.S. and point to the importance of age during her trip ${ }^{86}$.

These rich moments in Rosalie, Victoria, and Eleanor's travel writing demonstrate that the hopes of educators and adults were borne out in some cases but not in others. When youth encountered the political differences between the U.S. and the countries they visited, they did reflect on their national identity and the country's place in the world and, in some moments, did become more attached to the U.S. Yet, their travel writing clarifies that gender and age were very important for how the youth made sense of what they experienced-factors unanticipated by the adults writing in American publications and thus ways in which the youths imbued their experiences abroad with their own meaning.

\footnotetext{
${ }^{85}$ Ibidem, Aug. 16-20, 1936, p. 5

${ }^{86}$ The youths' writing about the legacy of World War One, whether it be seeing relics in museums, visiting cemeteries and battlefields, or speaking with Europeans, is another way they engaged with political issues. For example, Rosalie connected the «hospitality» of the Belgium people to them being grateful to «how the United States fed the people of Belgium during the last war under the direction of Herbert Hoover». Rosalie McLeod Diary, Aug. 27, 1937, p. 39. In contrast, Anna wrote while in Germany, «I do not like Germans, even tho [sic] I was so young in the time of the war I can't get over how horrible they were». Anna Taylor Diary, July 30 and 31, 1929.
} 


\section{Conclusion}

«I'm glad I'm here [in the United States] but I would like to be back in Europe for I love it so over there».

Anna, 1929

«I won't be entirely happy till I come again».

Yvonne, 1930

«Had a marvelous time but I'm afraid I'll never be content to stay home again, very long».

Clara, 1933

Though the youths' journeys lasted no more than a few months, quotes like the ones above and their actions later in life indicate how their trips continued to influence them ${ }^{87}$. Anna, Yvonne, and Clara, the youth who kept diaries throughout the entire year, reflected on their trips that fall and into the winter and maintained relationships with those they traveled with. For example, Clara assembled her travel group for a party and Anna kept up correspondence with a young man she met on the ship. Clara also paid attention to the political climate in Europe, writing on Saturday, November 14, two days after the German referendum, «Adolf Hitler announces Germany's resignation from the League of Nations and disarmament conference. Whole world in turmoil» - an event that likely prompted her to reflect on her trip ${ }^{88}$. Furthermore, both Rosalie and Eleanor revisited their diaries years later in order to transcribe them. Although we do not know if Victoria, Clara, or Anna returned to their travel writing later in life, it is hard to imagine that they did not reflect on their trips, especially with the onset of the Second World War within a decade after they returned home. Additionally, passenger lists indicate that some of the youths indeed returned to Europe - Victoria in 1949 and 1950 and Clara in 1939. All of which suggests that what they encountered as youths abroad continued to shape how they understood themselves and their Americanness throughout their lives ${ }^{89}$.

These young Americans' trips become particularly poignant when put in conversation with scholarship on tourism that stresses the importance of travel and travel writing for American

\footnotetext{
${ }^{87}$ Anna Taylor Diary, Sept. 10, 1929; Yvonne Blue Travel Diary, Aug. 3, 1930, p. 99; Clara Schiefer Diary, Memoranda, p. 368.

${ }^{88}$ Clara Schiefer Diary, Nov. 14, 1933, pp. 287, 335. Rosalie transcribed her diary as a gift for her father and Eleanor published her diary in the Rocky Mountain Jewish Historical Notes. See: «A Journey to Poland: August 1936», in Rocky Mountain Jewish Historical Notes, 6, 3/1984.

${ }^{89}$ For Victoria Brown's return trips see: “New York Passenger Lists, 1820-1957," New York, NY, 28 October 1949, Scanned Image, Ancestry.com Roll 7752, Line 10; and 24 Oct. 1950, Scanned Image, Ancestry.com Roll 7906, Line: 23, Page: 11. For Clara Louise's trip see: “New York Passenger Lists, 1820-1957,” New York, NY, 4 Sept., 1939, Scanned Image, Ancestry.com Roll 6393, Line: 28, Page: 158. All accessed March 3, 2017. Eleanor also reflected on her trip in an oral history she did in 1984. See Oral History Interview with Eleanor Judd, op. cit.
} 
intervention abroad. Christopher Endy has specifically argued that travel abroad «influenced views of the specific European countries and promoted U.S. intervention on behalf of the Allied powers in World War $1 »^{90}$. Thus, what the youth saw and people whom the youth met as they traveled likely shaped their views of Europe and Europeans leading up to World War Two and how they viewed American policy during the war.

As the close readings of their travel writings indicate, age and gender were central to how these youths negotiated the meaning of home and the U.S.' place on the international stage. Their travel writing confirms and complicates the portrait of youth travel offered in the publications Americans read. Indeed, going abroad did foster a national and international mindedness, but this national and international mindedness did not just come through experiencing different cultures. Interactions with other young people in international spaces informed how the youths came to terms with what it meant to be an American, and specifically a young American abroad. Whether it was participating in controversial youth habits or grappling with political issues as they traveled, how these American youths made sense of their travels and themselves as Americans was in large part defined by their experiences growing up during a period in which anxieties about youth, gender, and young women's sexuality were high.

\footnotetext{
${ }^{90}$ For the role of travel and travel writing in American intervention abroad see: ENDY, Christopher, op. cit., p. 565; GREENBERG, Amy S., Manifest Manhood and the Antebellum American Empire, Cambridge, Cambridge UP, 2005; HOGANSON, Kristen, Fighting For American Manhood: How Gender Politics Provoked the Spanish-American and Philippine-American Wars, New Haven, Yale UP, 1998.
} 


\section{THE AUTHOR}

Katherine CARTWRIGHT is a Ph.D. candidate at The College of William \& Mary. Her research looks at how American young people engaged in and shaped efforts aimed at cross-cultural understanding and internationalism from World War One through World War Two. She seeks to prioritize children and youth in her research by incorporating their voices and using sources they produced.

URL: < http://www.studistorici.com/progett/autori/\#Cartwright > 